\title{
LQR control of interleaved double dual boost converter for electrical vehicles and renewable energy conversion
}

\author{
J. S. V. Siva Kumar' ${ }^{1}$, P. Mallikarjunarao² \\ ${ }^{1}$ Department of Electrical and Electronics Engineering, Andhra University, India \\ ${ }^{2}$ Department of Electrical Engineering, Andhra University, India
}

\begin{tabular}{l} 
Article Info \\
\hline Article history: \\
Received Mar 1, 2019 \\
Revised Apr 12, 2019 \\
Accepted Jun 28, 2019 \\
\hline
\end{tabular}

Keywords:

Interleaved double dual boost converter

LQR control

Non-isolated boost converter

\begin{abstract}
The automobile industry is one of the major industries that are having its new innovations at a great pace according to the requirements of the day-to-day life. Due to the usage of conventional vehicles on a large scale which usually use petroleum products as fuel, is leading to a vast environmental effect, mainly due to the emission of greenhouse gases. So in order to reduce the ill effects of the greenhouse gas emissions great efforts are being put in manufacturing of electrical vehicles. Among the currently available greenhouse technologies the fuel cell provides high energy density in spite of its expenses. So, in this aspect a required mechanism has to be adopted to make it energy efficient and affordable. In order to overcome the drawback of fuel cell i.e. low output voltage, the boost converters are to be used and to be more precise Non-isolated Interleaved Double Dual Boost (IDDB) converters are recommended which makes it efficient and also the reduction of overall vehicle weight can be achieved. The LQR control technique is applied in this work to make the transient response of the fuel cell powered IDDB converter for various load conditions effective. The verification of results is done with simulation techniques using MATLAB/Simulink.
\end{abstract}

Copyright $\odot 2019$ Institute of Advanced Engineering and Science. All rights reserved.

\section{Corresponding Author:}

J. S. V. Siva Kumar,

Department of Electrical and Electronics Engineering,

Andhra University, GMRIT, Rajam, India.

Email: jsvsivakumar99@gmail.com

\section{INTRODUCTION}

In the development of economy, the transportation plays a vital role. But in recent studies it is observed that in most of the cities with high population density, the quality of atmospheric air is being decremented due to the emission of greenhouse gases from conventional vehicles. Hence, the transportation with the utilisation of the electrical vehicles overcomes these ill effects on the environment and results in the eco-friendly transportation. The components that are incorporated in an electrical vehicle are battery, ultra-capacitor and fuel cell (FC) which acts as an energy source for the propulsion system. Among the above stated, the fuel cell is found to be the better primary source of energy in the EV because of its high power density and green source of electrical energy. Since the response of the FC is slower it leads to the poor response during the sudden variations in loads. Hence, the ultra-capacitor is effective for the propulsion system in the dynamic conditions. The characteristics of ultra-capacitor are high energy density and low power density which leads to the charging and discharging at a faster rate and hence allowing the ultracapacitor to provide energy in case of transients [1-3].

Generally the voltage level of a FC is very low but the voltage level of a drive motor to which the FC supplies energy is of high level. So the step up chopper is necessary to boost the level of voltage of FC [4]. But at that voltage gain conditions, the maintenance of the efficiency is a typical task [5-8]. For a given power condition, low voltage leads to the high current which in turn makes the boost converter to be operated 
at small duty cycles which increases the size of the inductor, output capacitor and also increases the losses which finally results in the low efficient converter [9].

Hence, the high power converters are necessary to boost the voltage level of FC and handle the high voltage and current at output and input respectively without impacting the efficiency for the high power applications such as EV. By interleaving multiple conventional-boost converters the problem can be handled and it's the most efficient way.

In this paper we assess the feasibility of the interleaved double dual boost converter to attain higher voltage gain in comparison to the classical boost converter [10-14]. The similar modelling is to be chosen among others that too have high gain properties [15-23] because it leads to the likelihood of phase interleaving which in turn permits the modular characteristics of converter applicable for high power applications.

In electrical vehicles, the perturbations of load which occur typically. Even at such conditions, to regulate the output voltage at nominal values, the controller having higher efficiency is required. In this work a LQR control of an interleaved double dual boost converter was presented [24] and its efficacy is verified under different load disturbances using the simulation techniques of matlab/Simulink.

\section{MODELING OF THE TWO-PHASE CONVERTER}

\subsection{Topology}

The IDDB having two phases is illustrated in the Figure 1, in which the load is represented by Ro. Each phase of the converter consists of conventional boost module with an inductor along with its respective pair of switches. Here "module1" denotes phase1 and capacitor $\mathrm{C} 1$ and vice-versa.

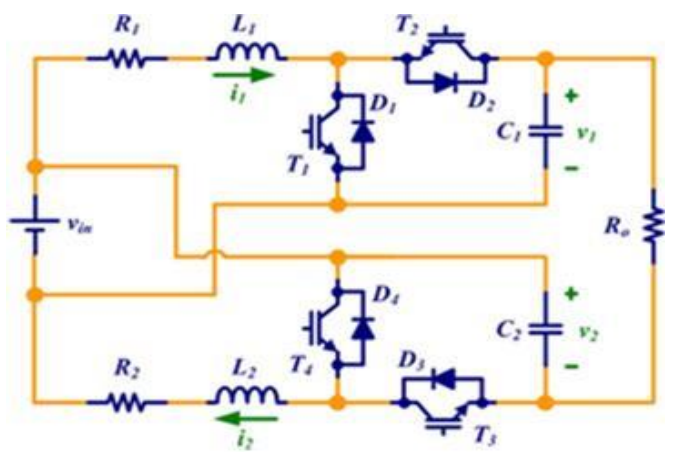

Figure 1. IDDB with two phases

The resistors R1 and R2 represent the lumped internal resistances of the inductor and the switches. In this topology of the converter each switch is represented by a transistor and an anti-parallel diode aiding bidirectional flow of power necessary for accommodating energy storage devices such as batteries and ultra-capacitors.

The output voltage $v_{o}$ (i.e., the voltage at the load $R_{o}$ ) is given by:

$\mathrm{v}_{\mathrm{o}}=\mathrm{v}_{1}+\mathrm{v}_{2}-\mathrm{v}_{\text {in }}$

The source current of the converter is given by:

$$
\mathrm{i}_{\text {in }}=\mathrm{i}_{1}+\mathrm{i}_{2}-\mathrm{i}_{\mathrm{o}}
$$

where $\mathrm{i}_{\mathrm{o}}=\mathrm{V}_{0} / \mathrm{R}_{0}$ is the output current of the converter.

\subsection{Converter Model with Reduced Order}

The two-phase IDDB with bi-directional switches is shown in Figure 2. Where duty cycle of the switch $S_{1}$ is represented by $\delta_{i}$ and indicates inductor charging mode by connecting the inductor parallel to the source $\left(\mathrm{V}_{\text {in }}\right)$. It assumes that the duty cycle is in conjunction to the conduction of lower transistor for the switch $\mathrm{S}_{1}$ of module1 while in case of module2 it indicates the conduction of the upper transistor, switch $\mathrm{S}_{2}$. 


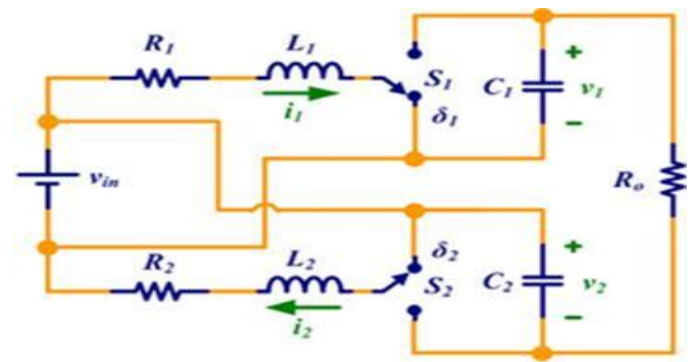

Figure 2. Two-phase IDDB with two-way switches

The state-space model of the converter can be written as:

$\dot{x}=A x+B u$.

Since the converter has four energy storing elements, the system represents a fourth order system, and the state vector $\mathrm{x}$ is given by (4) representing the average values of the variables

$\boldsymbol{x}_{2} p \boldsymbol{p}=\left[\begin{array}{llll}\mathrm{I}_{1} & \mathrm{~V}_{1} & \mathrm{I}_{2} & \mathrm{~V}_{2}\end{array}\right]^{\mathrm{I}}$

The system has only one input and is given as:

$\boldsymbol{u}=\left[\mathrm{V}_{\text {in }}\right]$.

Using the state-space averaging method [2] and using the notation $\delta_{\mathrm{i}}=\left(1-\delta_{\mathrm{i}}\right)$, the state matrix is given by:

$$
A_{2_{-} p h}=\left[\begin{array}{cccc}
\frac{-R_{1}}{L_{1}} & \frac{-\bar{\delta}_{1}}{L_{1}} & 0 & 0 \\
\frac{-\bar{\delta}_{1}}{C_{1}} & \frac{-1}{R_{0} C_{1}} & 0 & \frac{-1}{R_{0} C_{1}} \\
0 & 0 & \frac{-R_{2}}{L_{2}} & \frac{-\bar{\delta}_{2}}{L_{2}} \\
0 & \frac{-1}{R_{0} C_{2}} & \frac{-\bar{\delta}_{2}}{C_{2}} & \frac{-1}{R_{0} C_{2}}
\end{array}\right]
$$

While the input matrix is given by:

$$
B_{2-p h}=\left[\begin{array}{llll}
\frac{1}{L_{1}} & \frac{1}{R_{0} C_{1}} & \frac{1}{L_{2}} & \frac{1}{R_{0} C_{2}}
\end{array}\right]^{I} \mathrm{I}
$$

Now, a perfect symmetry among the phases will be considered, i.e.

$\mathrm{L}_{1}=\mathrm{L}_{2}=\mathrm{L}$

$\mathrm{R}_{1}=\mathrm{R}_{2}=\mathrm{R}$

$\mathrm{C}_{1}=\mathrm{C}_{2}=\mathrm{C}$

$\mathrm{V}_{1}=\mathrm{V}_{2}=\mathrm{V}$

For the controller design, the system can now be written as two independent systems of order two, one for each module, the first of them having the following state vector:

$$
x_{2_{-} p h}^{1}=\left[\begin{array}{ll}
I & V
\end{array}\right]^{1}
$$

The reduced system matrix and the reduced input matrix are then given by:

$$
\mathrm{A}_{2 \_ \text {ph_red }}=\left[\begin{array}{cc}
\frac{-R}{L} & \frac{-\bar{\delta}}{L} \\
\frac{-\bar{\delta}}{C} & \frac{-2}{R_{0} C}
\end{array}\right] \quad \mathrm{B}_{2 \_ \text {ph__red }}=\left[\begin{array}{c}
\frac{1}{L} \\
\frac{1}{R_{0} C}
\end{array}\right]
$$


The generated reduced-order system represents the current and voltage dynamics of the corresponding module.

Assumption 1: Two modules of the converter are symmetric.

The variable duty cycle $\delta$ is similar to both the modules. The model is concerned with the voltages across capacitors which is having an indirect relationship with output voltage. Yet, it is evident that the output voltage directly depends on the input voltage. This infers that any change in input voltage reflects in the variation of the output voltage and the compensation can be done by regulating output-capacitor voltage references. If any attempt is made to directly control the output voltage by ignoring module voltages it would lead to an imbalance of these voltages which results in distorted symmetry in the wave shape.

\section{MODELING OF THE N-PHASE CONVERTER}

As stated, this topology facilitates modular structure permitting more than two phases. For attaining symmetry, even multiple of phases are preferred. This section is to hypothesize the modelling of converter to N-phase topology.

The coalition of the phases that are connected to the capacitor $C_{1}$ and capacitor $C_{2}$ itself forms module-1 and vice versa in case of module-2. As a validation, the six-phase converter is illustrated in Figure 3 to portray multiple phases.

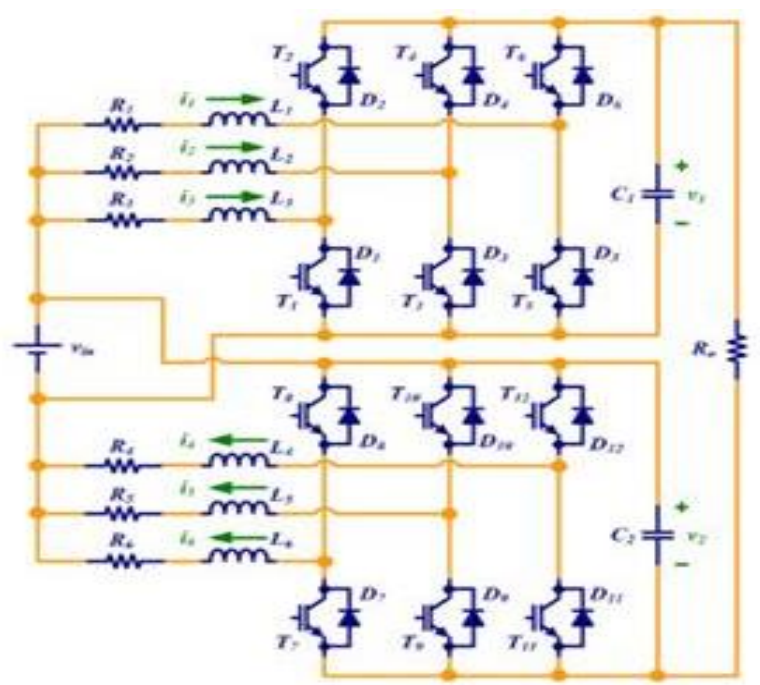

Figure 3. Six phase IDDB converter

The source current is given by:

$$
i_{\text {in }}=i_{1}+i_{2}+i_{3}+\ldots \ldots+i_{N}-i_{0}
$$

The $\mathrm{N}$-phase IDDB has $\mathrm{N}+2$ state variables, here chosen as the representing ' $\mathrm{N}$ ' inductor currents and two capacitor voltages.

The differential equation for the current in each of the N/2 inductors of module 1 is given by:

$$
\frac{d}{d t} I_{k}=\frac{1}{L_{k}}\left(-R_{k} I_{k}-V_{1} \bar{\delta}_{k}+V_{\text {in }}\right)
$$

for $k=1 \ldots, N / 2$. Similarly for $k=(N / 2)+1$ to $N$

The differential equation for the voltage in $\mathrm{C} 1$ is given by $\mathrm{V} 1$

$$
\frac{d}{d t} V_{1}=\frac{1}{C_{1}}\left[\left(\sum^{\frac{N}{2}}{ }_{k=1} I_{k} \bar{\delta}_{k}\right)+\frac{-V_{1}-V_{2}+V_{i n}}{R_{0}}\right]
$$


Similarly for voltage aceoss $\mathrm{C}_{2}$

Now, by exploring the symmetry of the system same like two phase all inductances and capactors are same and also, using the same current reference for the currents of each module, the current in every phase is the same, i.e.,

$$
\mathrm{I}_{1}=\mathrm{I}_{2}=\ldots \ldots=\mathrm{I}_{\mathrm{N}}=\mathrm{I}
$$

and the duty cycle is the same for all phases, i.e.,

$$
\delta_{1}=\delta_{2}=\ldots \ldots=\delta_{\mathrm{N}}=\delta
$$

Then,

$$
\frac{d}{d t} I=\frac{1}{L}\left(-R I-V \bar{\delta}+V_{i n}\right)
$$

And,

$$
\frac{d}{d t} V=\frac{1}{C}\left[\frac{(N \bar{\delta} I)}{2}+\frac{-2 V+V_{i n}}{R_{0}}\right]
$$

In the state-space form, the state vector is

$$
X=\left[\begin{array}{ll}
I & V
\end{array}\right]^{I}
$$

while the system and input matrix are

$$
\mathrm{A}=\left[\begin{array}{cc}
\frac{-R}{L} & \frac{-\bar{\delta}}{L} \\
\frac{N \bar{\delta}}{2 C} & \frac{-2}{R_{0} C}
\end{array}\right] \quad \mathrm{B}=\left[\begin{array}{c}
\frac{1}{L} \\
\frac{1}{R_{0} C}
\end{array}\right]
$$

Table 1 Parameter Values

\begin{tabular}{ccc}
\hline Parameter & Description & Value \\
\hline$V_{i n}$ & Input voltage & $60 \mathrm{~V}$ \\
$R$ & Series Resistance & $0.15 \Omega$ \\
$L$ & Inductance & $535 \mu \mathrm{H}$ \\
$C$ & Capacitance & $470 \mu \mathrm{F}$ \\
$R_{o}$ & Load Resistance & $59 \Omega$ \\
$f_{s w}$ & Switching Frequency & $10 \mathrm{kHz}$ \\
$\delta$ & Duty cycle & 0.73 \\
\hline
\end{tabular}

\section{METHODOLOGY OF LQR CONTROLLER}

The finite horizon, linear quadratic regulator $(\mathrm{LQR})$ is given by:

$$
\dot{x}=A x+B u \quad y=C x \quad x \in \mathfrak{R}^{\mathrm{n}}, u \in \mathfrak{R}^{\mathrm{m}}, y \in \mathfrak{R}^{p}, x_{0} \text { give } J=\frac{1}{2} \int_{0}^{T}\left(x^{T} Q x+\boldsymbol{u}^{T} \boldsymbol{R u}\right) d t
$$

where $\mathrm{Q} \geq 0, \mathrm{R}>0, \mathrm{P}_{1} \geq 0$, are symmetric, positive (semi-) definite matrices. The $\mathrm{Q}$ and $\mathrm{R}$ are weight matrices for states and control input respectively, as shown in Figure 4.

The LQR control input is given by $u=-k x$. ' $k$ ' is LQR gain and is given by $k=R^{-1} B^{T} P$ And 'P' can be obtained from algebraic Ricatti equation solution of :

$A^{T} P+P A-P B R^{-1} B^{T} P+Q=0$ 


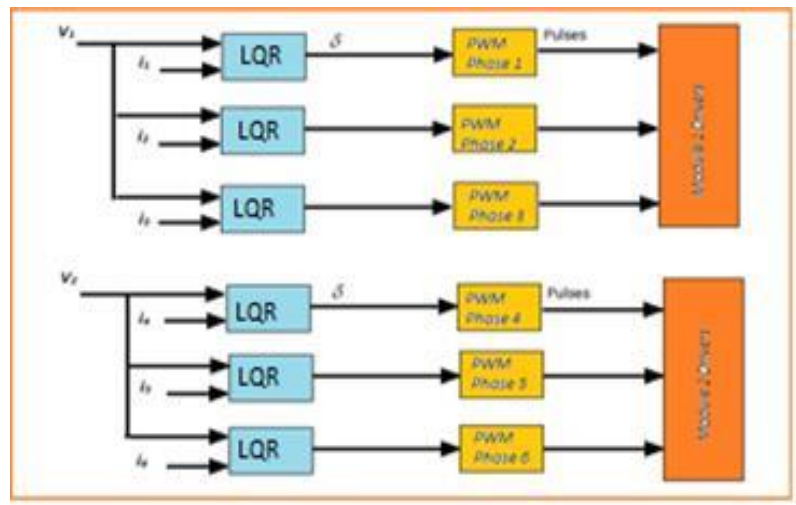

Figure 4. Control diagram of the implemented controllers

\section{RESULTS AND DISCUSSION}

The IDDB converter is modelled and the functioning of the system is verified on matlab/simulink by employing LQR controller. The results of whole system parameters are illustrated below. Here, two phase and six phase IDDB converter with LQR controller simulation results are explained.

The PWM pulses which are fed to two first-phase IGBTs are interpreted in Figure 5. From the Figure it can be concluded that both the switches are operating simultaneously. The currents flowing through the inductance of the one of the phase are illustrated in Figure 6. From the figure it is evident that the current in each inductance possess a current ripple of $8 \mathrm{~A}$. So that the size of inductance $\mathrm{L}_{1}$ and $\mathrm{L}_{2}$ can be reduced as well as power handling capacity of the conventional boost converter can be increased by using IDDB converter.

Output current is shown Figure 7 and from this it is observed that the output current value is maintained constant.
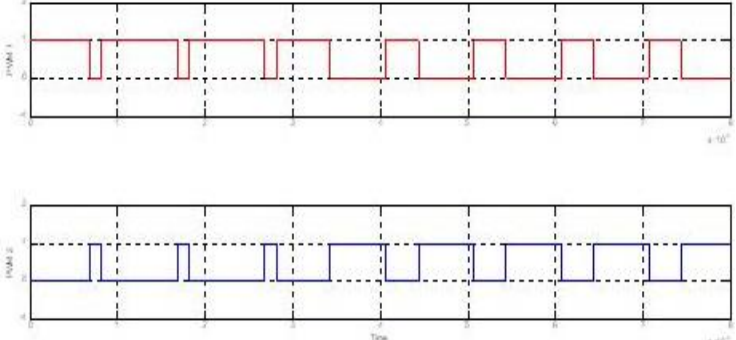

Figure 5. PWM pulses to IGBTs

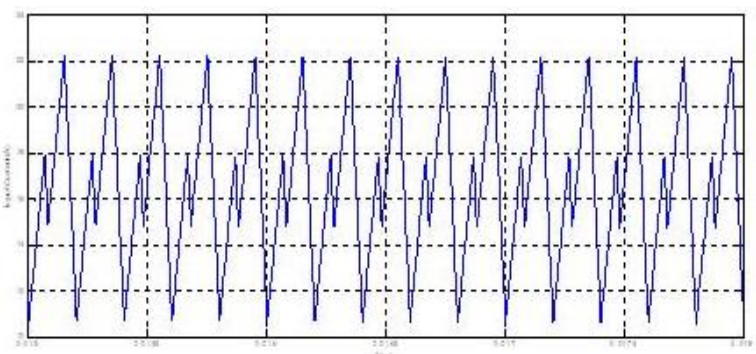

Figure 6. Input current to two phase IDDB

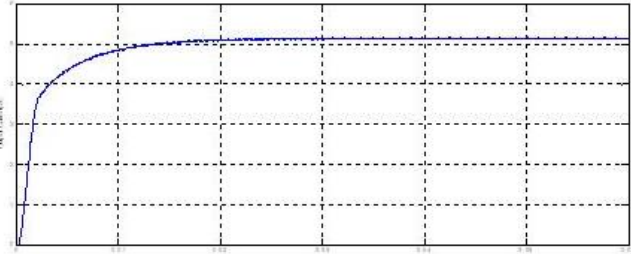

Figure 7. Output current of two phase IDDB
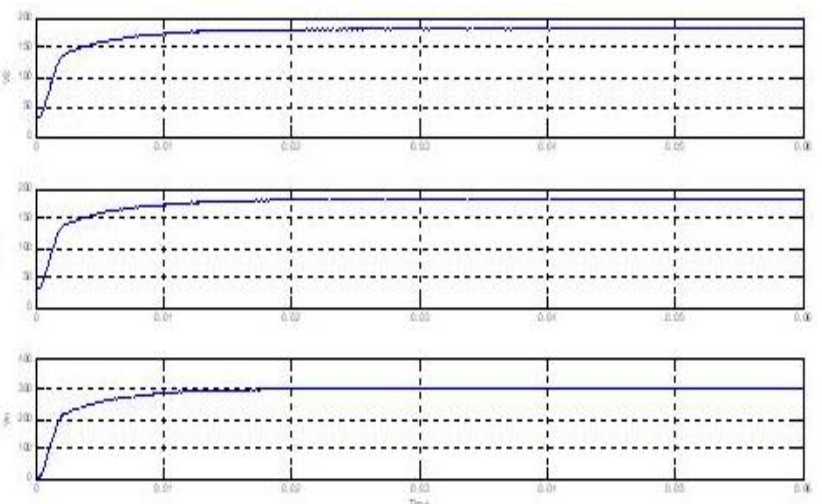

Figure 8. Output voltage of two phase IDDB 
The output voltage and voltage across the capacitors in both phases are is illustrated in Figure 8 . From the above it can be observed that the output voltage is regulated at the reference point and capacitor voltages are also constant for the given $60 \mathrm{~V}$ input with the utilization of LQR controller. It is evident from the above Figure 8 that the fuel cell voltage i.e.; $60 \mathrm{~V}$ is boosted to $300 \mathrm{~V}$ with the utility of IDDB converter and maintaining constant $300 \mathrm{~V}$ at load side with the help of LQR controller.

The dynamic functioning of the LQR controller is also evaluated. Figure 9 shows its effectiveness for a step load change at $0.02 \mathrm{sec}$, where the input voltage regulated by LQR controller can recur to the nominal value after a regulating period by regulating the output voltage to the desired value in a short time. However, in practice, parameter variations may glide into the components. In order to evaluate the validity of the adopted simplifications, the full-system model variations in the components have been considered.

In six phase IDDB, The current flowing through the inductance one of of the phases is shown in Figure 11. From the above it is clearly observed the current in each inductance is varying from $4 \mathrm{~A}$ to $16 \mathrm{~A}$ respectively. Output current is shown Figure 10. In this it is realized that the output current value is maintained constant.

As the numbers of phases are increasing with the same input voltage, the input current value is reduced but the output current value incremented to the value near to $5 \mathrm{~A}$ to $7 \mathrm{~A}$ by tuning the values of $\mathrm{Q}$ and $\mathrm{R}$. As a result, the output voltage also increased nearly to value of $300 \mathrm{~V}$ to $450 \mathrm{~V}$ and is illustrated in Figure 12. With this we can draw a conclusion that increasing the number of phases in IDDB with same input results in increase of power handling capability of the converter.

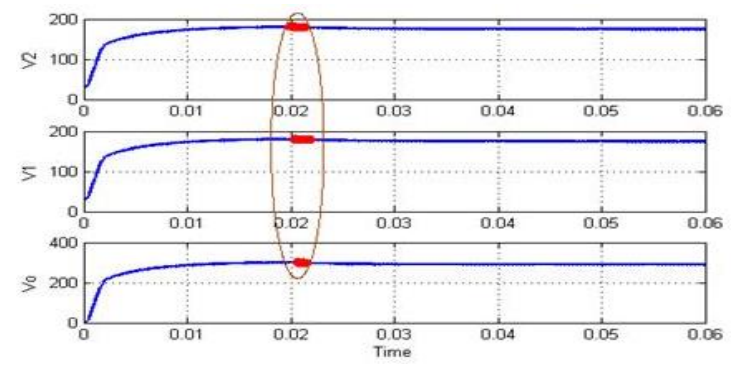

Figure 9. Waveforms of the converter in Dynamic state

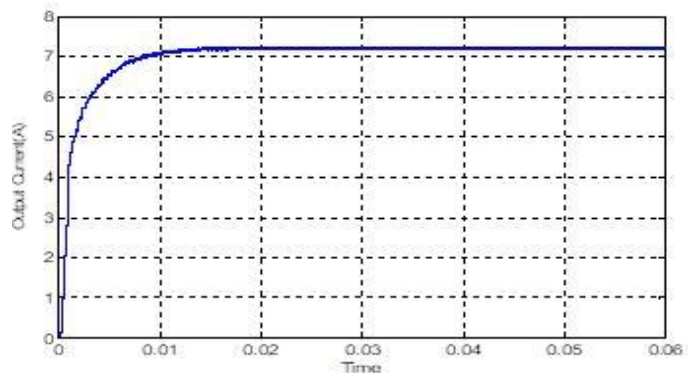

Figure 10. output current to six phase IDDB

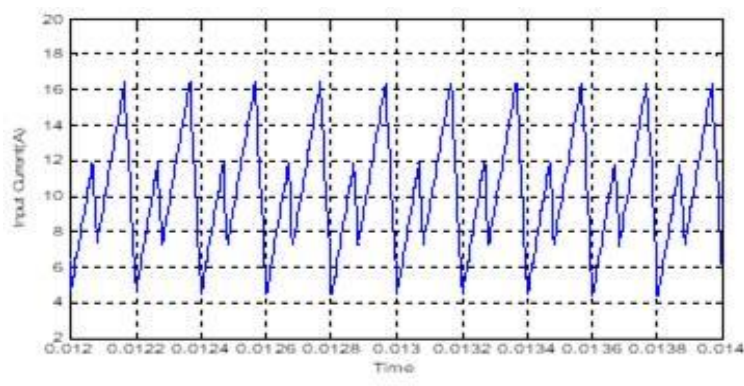

Figure 11. input current to six phase IDDB
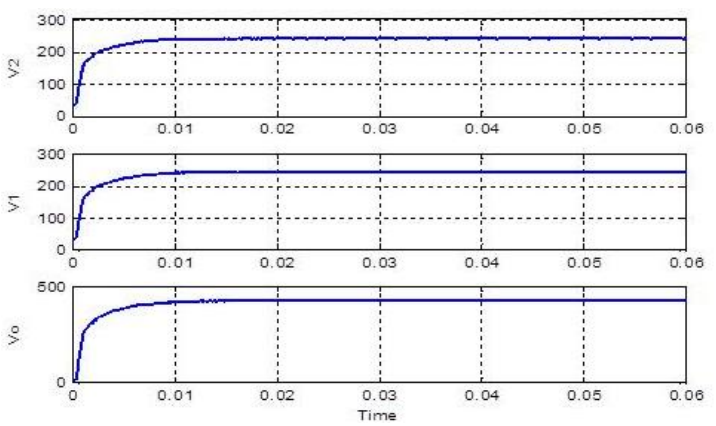

Figure 12. Output voltage of six phase IDDB 


\section{CONCLUSION}

In this paper the briefing of the modelling of the general N-phase IDDB and small signal analysis has been accomplished. The LQR control design for this converter has been illustrated for two-phase as well as six-phase IDDB. From the results it is obvious that the number of phases and the power handling capability of the converter are in direct proportion to each other. Hence, the upgrading of converter can be performed with more number of phases based on the load requirements. The utilization of symmetry of the converter and the control action is done in order to attain reduction in the complexity of the model. Simulation results in MATLAB/Simulink were equipped for backing the theoretical analysis.

\section{REFERENCES}

[1] H. El Fadil, F. Giri, S. M. Ieee, J. M. Guerrero, and S. Member, "Modeling and Nonlinear Control of FC/Supercapacitor Hybrid Energy Storage System for Electric Vehicles," vol. 63, no. 7, pp.3011- 3018, 2014.

[2] P. Thounthong, S. Pierfederici, J. Martin, M. Hinaje, and B. Davat,"Modeling and Controlof FC/Supercapacitor Hybrid Source Based on Differential Flatness Control," vol. 59, no.6, pp.2700- 2710,2010.

[3] J. Larminie and J. Lowry, Electric Vehicle Technology Explained,vol. 42, no. 1. 2003.

[4] M. Sedighizadeh and Z. Tirkan, "Proton Exchange Membrane FC Control Using a State Feedbac Controller Based on LQR," no. 1, pp. 480-484, 2010.

[5] D. D. Boettner, G. Paganelli, Y. G. Guezennec, G. Rizzoni, and M. J. Moran, "Proton Exchange membrane FC system model for automotive vehicle simulation and control," J. Energy Resour Technol. Trans. ASME, vol. 124,no. 1, 2002.

[6] A. Y. Karnik, J. H. Buckland, and J. Sun, "Performance of a PEM FC Water Management System Using Static Output Feedback," pp.2997-3002, 2007.

[7] P. Thounthong, P. Sethakul, S. Ra"el, and B. Davat, "Control of FC/battery/supercapacitor hybrid source for vehicle applications, ” in Proc. IEEE Int.Conf. Ind. Technol., 2009, pp.1-6.

[8] P. Thounthoung, V. Chunkag, P. Sethakul, and B. Davat, "Comparative study of FC vehicle hybridization with battery or supercapacitor storage device,” IEEE Trans. Veh. Technol., vol.58, no. 8, pp. 3892-3904, Oct. 2009.

[9] A. S. Samousir, M. Anwari, A. H. M. Yatim, "Dynamic Evolution Control of Interleaved Boost DC- DC Converter for Fuel Cell Application"pp 869-874,2010.

[10] B. V. Dang, Y. Lembeye, J. P. Ferrieux, J. Barbarroux, and Y. Avenas, "New high-power high-ratio non isolated $d c-d c$ boost converter for fuel cell applications," in Proc. IEEE Power Electron. Spec. Conf., 2006, pp. 1-7.

[11] P. Thounthong, P. Sethakul, and B. Davat, "Modified 4-phase interleaved fuel cell converter for high-power highvoltage applications, ” in Proc.IEEE Int. Conf. Ind. Technol., 2009, pp.1-6.

[12] K. Kajangpan and B. Neammenee, "High gain double interleave technique with maximum peak power tracking for wind turbine converter," in Proc. 6th Int. Conf.Telecommun. Inf. Technol., 2009, pp. 292-295.

[13] F. S. Garcia, J. A. Pomilio, and G. Spiazzi, "Modeling and control design of the six-phase interleaved double dual boost," in Proc. 9th IEEE/IAS Int.Conf. Ind. Appl., 2010, pp.1-6

[14] S. Choi, V. G. Agelidis, J. Yang, D. Coutellier, and P. Marabeas, "Analysis, design and experimental results of a floating- output interleaved-input boost-derived dc-dc high-gain ransformer-less converter," IET Power Electron., vol. 4, no. 1, pp. 168-180, Jan. 2011.

[15] Y. Jang and M. M. Jovanovi'c, "Interleaved boost converter with intrinsic voltage-doubler characteristic for universal-line PFC front end, ”IEEE Trans.Power Electron., vol. 22, no. 4, pp. 1394-1401, Jul. 2007.

[16] H. Nomura, K. Fujiwara, and M. Yoshida, "A new dc-dc converter circuit with larger step-up/down ratio," in Proc. IEEE Power Electron.Spec.Conf., 2006, pp. 1-7.

[17] M. Kavitha, V. Elanangai, S. Jayaprakash, V. Balasubramanian,” Development of Regenerative Braking Concept for Electric Vehicle Enhanced with Bidirectional Converter" International Journal of Power Electronics and Drive System, Vol. 9, No. 4, pp. 1584-1590, Dec 2018.

[18] Nitin Kumar Saxena, Sirak Gebrehiwot, Degu Mena"Controller Design for Electric Motor Derived Vehicle," Indonesian Journal of Electrical Engineering and Informatics (IJEEI), vol/issue:6(2),pp.125-131,June 2018

[19] M. Kavitha and V. Sivachidambaranathan, "Comparison of Different Control Techniques for Interleaved DC-DC Converter,” International Journal of Power Electronics and Drive System, vol/issue: 9(2), pp. 641-647, 2018.

[20] M. Premkumar, K. Karthick, and R. Sowmya, "A Comparative Study and Analysis on Conventional Solar PV Based DC-DC Converters and MPPT Techniques”, Indonesian Journal of Electrical Engineering and Computer Science, Vol. 11, No. 3, pp. 831-838, September 2018.

[21] M. Nymand and M. Andersen, "High-efficiency isolated boost dc-dc converter for high-power low- voltage fuelcell applications," IEEE Trans.Ind. Electron., vol. 57, no. 2, pp. 505-514, Feb. 2010.

[22] A. Shahin, M. Hinaje, J.-P. Martin, S. Pierfederici, S. Rael, and B.Davat,"High voltage ratio dc-de converter for fuel-cell applications," IEEE Trans. Ind. Electron.,vol. 57, no. 12, pp. 3944-3955, Dec. 2010.

[23] S. K. Changchien, T. J. Liang, J. F. Chen, and L. S. Yang, "Novel high step-up dc-dc converter for fuel cell energy conversion system," IEEE Trans. Ind. Electron., vol. 57, no. 6, pp. 2007-2017, Jun. 2010.

[24] Y. P. Hsieh, J. F. Chen, T. J. Liang, and L. S. Yang, "Novel high step-up dc-dc converter with coupled-inductor and switched-capacitor techniques for a sustainable energy system," IEEE Trans.Power Electron.,vol. 26,no. 12, pp.3481-3490, Dec. 2011. 


\section{BIOGRAPHIES OF AUTHORS}

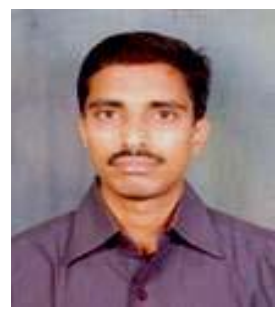

Sri J S V Siva Kumar received B.Tech degree, first class with distinction from JNTU, Hyderabad in 2002. He received M.Tech degree, first class with distinction from Vellore Institute of Technology, Vellore, Tamil Nadu in 2005. He is in the teaching profession for last 14 years. $\mathrm{He}$ is pursuing his $\mathrm{PhD}$ at Andhra University, Visakhapatnam, A.P,India. His research interests include power electronics and renewable energy sources. At present, he is working as Senior Assistant Professor in GMR Institute of Technology, Rajam,AP, India.

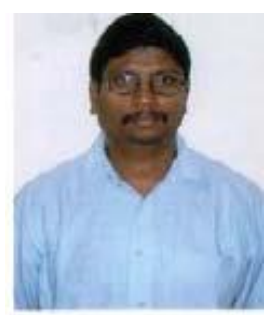

Dr. P. Mallikarjuna Rao, Presently working as Professor in Electrical Engineering Department, Andhra University college of Engineering, Andhra University, Visakhapatnam. He received M.Tech \& Ph.D degree from Andhra University, Andhra Pradesh. He is in the teaching Profession for past two decades. His research interest includes Control systems, advanced control of Electrical Machines and Control System applications in Electrical Engineering. $\mathrm{He}$ published various papers in National and International Journals and Conferences. He submitted various DST projects to NSTL, DRDO, ISRO. 